\title{
The use of exogenous microbial species to enhance the performance of a hybrid fixed-film bioreactor treating coal gasification wastewater to meet discharge requirements
}

\author{
E Rava ${ }^{1 *}$, E Chirwa', P Allison ${ }^{2}$, M van Niekerk $^{3}$ and MP Augustyn ${ }^{3}$ \\ University of Pretoria, Water Utilisation Division, 0002, South Africa \\ ${ }^{2}$ Scientific and Technical Consulting Services, P.O. Box 699, Port Alfred 6170, South Africa \\ ${ }^{3}$ Sasol Group Technology (Pty) Ltd, Private Bag X1034, IB4901, Secunda 2302, South Africa
}

\begin{abstract}
The objective of this study was to determine whether inoculating a hybrid fixed-film bioreactor with exogenous bacterial and diatoma species would increase the removal of chemical oxygen demand, nitrogenous compounds and suspended solids from a real-time coal gasification wastewater to meet environmental discharge requirements specified for petrochemical refineries. The COD removal increased by $25 \%(45 \%$ to $70 \%)$ at a relatively high inoculum dosage $\left(370 \mathrm{~g} \cdot \mathrm{m}^{-3}\right)$ and unit treatment cost $\left(12.21 € \cdot \mathrm{m}^{-3}\right)$. The molar ratio of monovalent cations to divalent cations $(\mathrm{M} / \mathrm{D}>2)$ affected nitrification, settling of solids and dewatering of the sludge. The use of a low-charge cationic flocculant decreased the suspended solids in the effluent by $70 \%\left(180 \mathrm{mg} \cdot \mathrm{L}^{-1}\right.$ to $\left.54 \mathrm{mg} \cdot \mathrm{L}^{-1}\right)$ and increased the sludge dewatering rate by $88 \%\left(61 \mathrm{~s} \cdot \mathrm{L} \cdot \mathrm{g}^{-1}\right.$ to $\left.154 \mathrm{~s} \cdot \mathrm{L} \cdot \mathrm{g}^{-1}\right)$ at a unit treatment cost of $2.5 € \cdot \mathrm{t}^{-1} \mathrm{dry}$ solids. Organic compounds not removed by the indigenous and exogenous microbial species included benzoic acids (aromatic carboxylic acids), 2-butenoic acid (short-chain unsaturated carboxylic acid), $\mathrm{I}(2 \mathrm{H})$-isoquinolinone (heterocyclic amine), hydantoins (highly polar heterocyclic compounds), long-chain hydrocarbon length (carbon length $>\mathrm{C}_{15}$ ) and squalene. These organic compounds can thus be classified as poorly degradable or nonbiodegradable which contributed to the $30 \%$ COD not removed by the H-FFBR. The use of exogenous microbial species improved the quality of CGWW; however, not sufficiently to meet discharge requirements. The cost of such treatment to meet discharge requirements would be unsustainable. Alternative technologies need to be investigated for reusing or recycling the CGWW rather than discharging.
\end{abstract}

Keywords: ammonia, catalytic reactor technology, COD, fixed-film bioreactor, hydantoins, thiocyanates

\section{INTRODUCTION}

Integrated refineries, such as those using the Lurgi coal gasification process, generate large volumes of wastewater with high concentrations of hazardous contaminants. The composition of coal gasification wastewaters (CGWW) and coking wastewater are similar with respect to the organic and inorganic constituents. However, the effluent from CGWW is more complex and contains more toxic recalcitrant hydrocarbons than coking wastewater (Li et al., 2011). Regulations regarding the discharge of wastewater from petrochemical processing facilities, of which coal gasification systems are a part, are becoming stricter, and therefore more efficient wastewater treatment systems are required before releasing the effluent into the environment (Rubalcaba et al., 2007).

The contaminants present in CGWW include phenols, cyanide, thiocyanates, polycyclic aromatic hydrocarbons, nitrogen-, oxygen- and sulphur-containing heterocyclic compounds, long-chain hydrocarbons, pyridine, and quinolone (Li et al., 2014). Most of these refractory organic compounds have been reported to be mutagenic and teratogenic in living organisms (Wang et al., 2012). To treat and recycle the CGWW will reduce the demand on water resources and also prevent environmental pollution (Li et al., 2014).

A number of biological treatments have been developed for treating CGWW including activated sludge (CAS), such

\footnotetext{
* To whom all correspondence should be addressed.

ฮ +27833978524 / e-mail: emrava@buckman.com

Received 9 June 2015; accepted in revised form 27 June 2016
}

as biological nitrogen removal (BNR) systems and sequencing batch reactors (SBRs), and fixed-film processes such as fluidised-bed reactors (FBRs) and membrane bioreactors (MBRs). Unfortunately, the conventional biological systems rely on mesophilic bacteria sourced from soil and wastewater, and which are not resistant to high levels of toxicity and lack pathways to break down the complex aromatic compounds found in CGWW. Moreover, bacteria from municipal treatment plants do not perform well under low chemical oxygen demand (COD) levels (below $125 \mathrm{mg} \cdot \mathrm{L}^{-1}$ ) and ammonia-nitrogen (below $15 \mathrm{mg} \cdot \mathrm{L}^{-1}$ ), despite high removal efficiencies of biological oxygen demand $\left(\mathrm{BOD}_{5}\right)$, phenols and cyanide (Zhou et al., 2014). Therefore, the H-FFBR together with the inoculation of exogenous microorganisms was investigated for the removal of COD, nitrogencontaining compounds, phenols and other organic compounds.

Bio-augmentation has been reported as being a feasible option to enhance the biological treatment of high strength CGWW (Bai et al., 2010) with the following advantages: higher reactor biomass, strong capacity to handle shock loadings, lower excess sludge production and increasing microbial population diversity in the bioreactor (Tavares dos Pasos et al., 2010). Biological treatment is viewed as a cleaner technology since chemicals are not used, it has a smaller carbon footprint, smaller water footprint, fewer emissions and a disposable sludge is generated (Ishak et al., 2012).

Bio-augmentation is the addition of a different gene pool with metabolic properties that complement the existing one to increase the degradation of organic compounds (Domde et al., 2007). The bacteria carry plasmid-encoded catabolic genes that increase the degradation potential of the indigenous population 
via horizontal gene-transfer, enabling direct inheritance by future generations without reproduction (OECD, 2010). The three main mechanisms of gene transfer are: (i) transformation - gene transfer resulting from the uptake of free extracellular DNA from the environment; (ii) conjugation - genetic material is transferred from one bacteria to another by cell-to-cell contact, which is significant for bacteria found in biofilms and bio-aggregates such as activated sludge; and (iii) transduction - transfer of genetic material between bacteria mediated by bacteriophages (Wasilkowski et al., 2012). Horizontal gene transfer can range between $0 \%$ and $14 \%$ and peaks on the third day. A higher concentration of inoculum does not increase gene transfer rate; however, a higher concentration of activated sludge cells is associated with an increase in gene transfer rate. A 20:1 (activated sludge: Pseudomonas putida) ratio was associated with the highest number of gene transfers (Pei and Gunsch, 2009).

Bio-augmentation using naturally adapted bacteria does not introduce other species into the environment since horizontal gene transfer is a common process and major driving force of bacterial adaptability and diversity in wastewater (OECD, 2010).

The objective of this study was to determine the cost and sustainability of inoculating a pilot H-FFBR with exogenous bacterial and diatoma species to increase the removal of COD, organic compounds, suspended solids and nitrogenous compounds from CGWW to meet environmental discharge requirements specified for petrochemical refineries.

This study differs from other bio-augmentation publications in that the pilot plant was fed continuously with real-time CGWW for a period of 18 months and the performance of the bioreactor was related to the actual financial cost of bio-augmentation. Most reported studies have been based on batch processes using synthetic CGWW under ideal laboratory conditions which does not reflect fluctuating conditions in an operational plant.

\section{MATERIALS and METHODS}

\section{Pilot plant design}

The stainless steel pilot plant H-FFBR (1 $000 \mathrm{~L})$ consisted of 3 aeration compartments, designated as Zone 1, Zone 2 and Zone 3, containing acclimatised fixed and suspended biomass, and a clarifier. The volume of each zone was approximately $250 \mathrm{~L}, 150 \mathrm{~L}$ and $600 \mathrm{~L}$ for Zone 1, Zone 2 and Zone 3, respectively (Fig. 1).

The AnoxKaldnes K1 plastic biofilm carrier filling fraction (based on volume) for the aeration zones was approximately $70 \%$ for Zone $1,50 \%$ for Zone 2 and 30\% for Zone 3. A 70\% filling of biofilm carrier media corresponded to an effective biofilm growth area equal to $350 \mathrm{~m}^{2} \cdot \mathrm{m}^{-3}$, with $50 \%$ fill equal to $250 \mathrm{~m}^{2} \cdot \mathrm{m}^{-3}$ and a $30 \%$ fill equal to $150 \mathrm{~m}^{2} \cdot \mathrm{m}^{-3}$ (Ratcliffe et al., 2006; Ayun et al., 2008). Each aeration zone was linked to a data collection system (DCS) and parameters such as temperature, dissolved oxygen (DO), recycling rate, feed rate, desludging rate, hydraulic retention time, $\mathrm{pH}$ and sludge retention time were controlled and optimised automatically.

\section{Reactor operation}

The CGWW was diluted to $33 \%$ to reduce the toxicity towards the biomass and to maintain an influent COD around $2000 \mathrm{mg} \cdot \mathrm{L}^{-1}$. Dilution was 1 part CGWW to 2 parts recycled activated sludge (RAS) and fed to Zone 1 of the H-FFBR. The reactor was operated at $36 \pm 1^{\circ} \mathrm{C}$ and monitored over a period of 64 weeks. The $\mathrm{pH}$ was adjusted with $20 \%(\mathrm{~m} / \mathrm{v})$ sulphuric acid $\left(\mathrm{H}_{2} \mathrm{SO}_{4}\right)$ or $10 \%(\mathrm{~m} / \mathrm{v})$ sodium hydroxide $(\mathrm{NaOH})$ to maintain a
$\mathrm{pH}$ of $8.0 \pm 0.5$. Food to mass ratio $\left(\mathrm{kg}-\mathrm{COD} \cdot \mathrm{m}^{-3} \cdot \mathrm{d}^{-1}\right)$ was maintained at $<0.45$ of the biodegradable COD fraction, sludge retention time (SRT) was about $18 \mathrm{~d}$ and the hydraulic retention time (HRT) was $33 \mathrm{~h}$. Dissolved oxygen (DO) level was maintained between $5 \mathrm{mg} \cdot \mathrm{L}^{-1}$ and $6 \mathrm{mg} \cdot \mathrm{L}^{-1}$.

\section{Sampling procedures}

Composite samples $(1000 \mathrm{~mL})$ of the influent stream (feed) and effluent stream (clarifier overflow) were collected daily and tested for $\mathrm{pH}$, calcium, magnesium, soluble COD (filtered through a $0.45 \mu \mathrm{m}$ membrane filter) and total COD, suspended solids, ammonium-nitrogen and nitrate-nitrogen, suspended solids, and capillary suction tests (CST). Grab samples (1000 mL) of the feed and effluent were taken monthly, extracted with dichloromethane and the extractions analysed ('finger-printed') by gas chromatography- mass spectroscopy (GC/MS).

\section{Preparation of exogenous inoculum}

The selectively adapted exogenous inocula, sourced from Buckman Africa, were mobilised by hydrating the respective inocula $(20 \% \mathrm{w} / \mathrm{v})$ using chlorine-free tap water and stirring using an over-head stirrer for $60 \mathrm{~min}$ at $80 \mathrm{r} \cdot \mathrm{min}^{-1}$. Hydration was required to resuscitate the freeze-dried cultures. The hydrated inocula were then filtered through a $100 \mu \mathrm{m}$ mesh to remove the carrier. For the purpose of this study, the exogenous inocula, i.e., XP16-014, XP16-015, XP16-016 and XP16-017 were labelled as PA1, PA2, PA3 and PA4, respectively.

\section{Oxygen uptake rate of bio-augmented samples}

The oxygen uptake rate (OUR) of laboratory-inoculated bioreactor samples $\left(20 \mathrm{mg} \cdot \mathrm{L}^{-1}\right.$ to $\left.250 \mathrm{mg} \cdot \mathrm{L}^{-1}\right)$ were measured on-site at $36 \pm 1^{\circ} \mathrm{C}$ using a calibrated HACH model HQ40d multi-meter with a LDO 101 dissolved oxygen probe. A biochemical oxygen demand (BOD) sample bottle $(300 \mathrm{~mL})$ was filled with $150 \mathrm{~mL}$ feed, bio-augmented with the respective hydrated products, and then filled up with $150 \mathrm{~mL}$ carrier media taken from the respective zones to simulate a $50 \%$ media fill fraction (by volume). The dissolved oxygen (DO) was measured every $60 \mathrm{~s}$ for a period of $10 \mathrm{~min}$. The OURs of the exogenous microbial species were calculated by linear regression obtained from the plot of DO concentration versus time. The choice of inocula for the pilot plant study was based on the OUR increase versus the unit treatment cost. The exogenous inocula selected were thus $50 \mathrm{mg} \cdot \mathrm{L}^{-1}$ for PA1, $150 \mathrm{mg} \cdot \mathrm{L}^{-1}$ for PA2, $150 \mathrm{mg} \cdot \mathrm{L}^{-1}$ for PA3 and $20 \mathrm{mg} \cdot \mathrm{L}^{-1}$ for PA4.

\section{Characterisation of the inoculum}

Hydrated mobilised micro-organisms were plated out for enumeration using Plate Count Agar (Oxoid CM0325) for heterotrophic plate counts (HPC) and Bacillus spp. Pseudomonas agar (Oxoid CM0579) supplemented with selective CFC supplement (SR0103) and selective CN supplement (Oxoid SR0102) was used for the enumeration of Pseudomonas species. Aeromonas medium base (Oxoid CM0833) supplemented with ampicillin (Oxoid SR0136) was used for the enumeration of Aeromonas species. All the agar plates were incubated at $35^{\circ} \mathrm{C}$ for $48 \mathrm{~h}$.

\section{Colony identifications and enumerations}

All colonies present on the respective agars were identified using the bioMèrieux VITEK MS automated microbial identification 


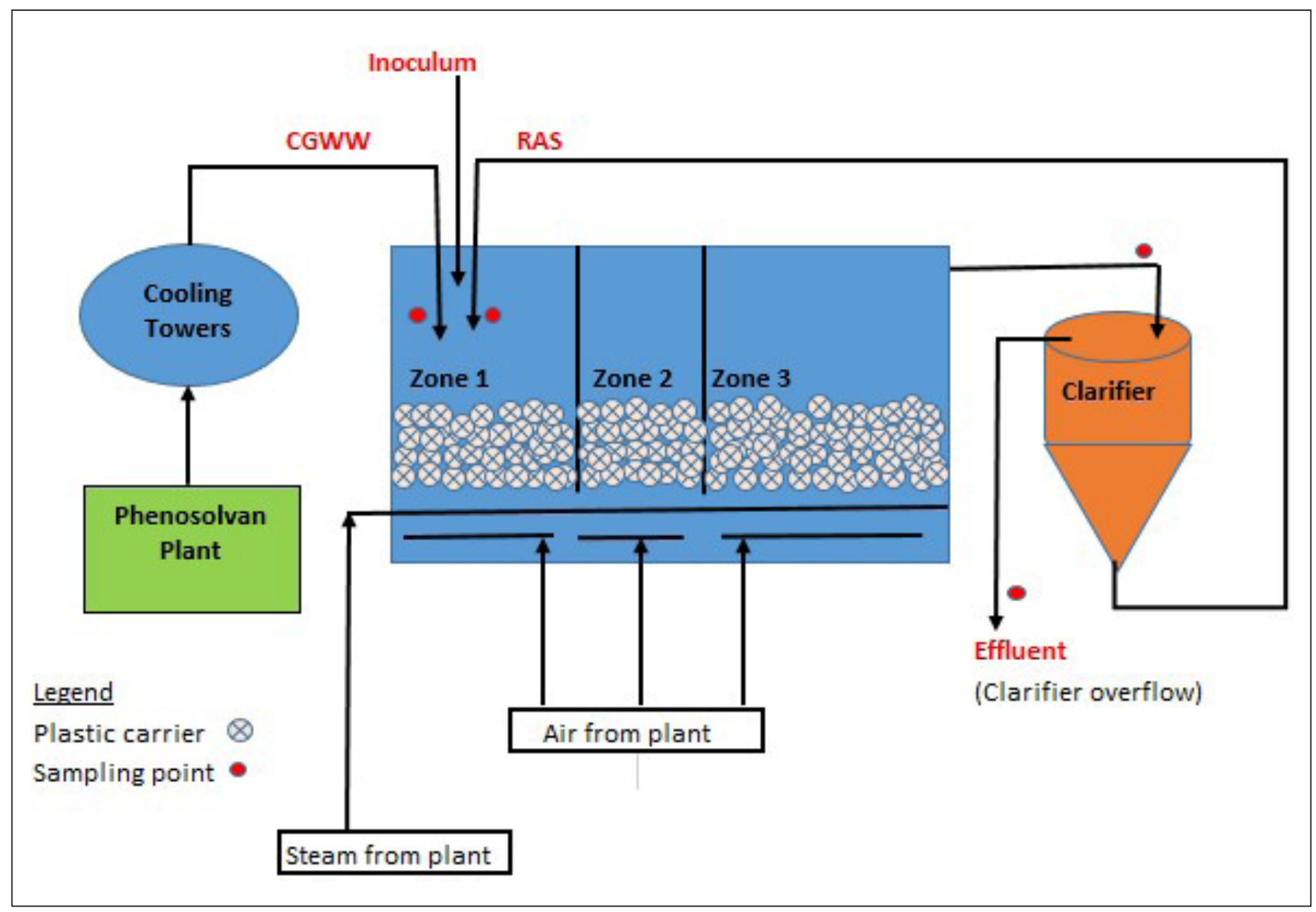

Figure 1

Configuration of the pilot plant hybrid fixed-film bioreactor (H-FFBR) used in this study

system that uses the Matrix Assisted Laser Desorption Ionization Time-of-Flight (MALDI-TOF) mass spectrometry technology. The sample is applied to a target slide and irradiated with a laser. The unique protein spectrum of the micro-organism is used for identification. The diatoma were identified using a standard microscope at 400x magnification and confirmed using an inverted microscope at $600 \mathrm{x}$ magnification.

Colony forming units (cfu) were multiplied by the respective dilution factors and converted from $\mathrm{cfu} \cdot \mathrm{mL}^{-1}$ to $\mathrm{cfu} \cdot \mathrm{g}^{-1}$. Diatoma counts were multiplied by the dilution factor and reported as cells. $g^{-1}$.

\section{Inoculation of the bioreactor}

The respective hydrated inocula were added daily directly into aeration Zone 1 of the H-FFBR. Each inoculation step was allowed to run for a period of 12 weeks to allow sufficient time ( 2 weeks to 3 weeks) for the exogenous micro-organisms to acclimatise to the CGWW and achieve maximum growth rate and biological activity. The reactor was subjected to 3 sludge ages (Stamoudis and Luthy, 1980).

\section{Flocculation and settling of the suspended solids in the clarifier}

Cationic flocculants, Sourced from Buckman Africa, were prepared as $0.1 \%(\mathrm{~m} / \mathrm{v})$ aqueous solutions and allowed to hydrate for $30 \mathrm{~min}$ before dosing. The flocculants were then dosed between $1 \mathrm{~kg} \cdot \mathrm{t}^{-1}$ and $3 \mathrm{~kg} \cdot \mathrm{t}^{-1}$ dry solids into $500 \mathrm{~mL}$ sample aliquots taken from the clarifier. Flocculation tests were performed using a Velp jar stirrer. The sample aliquots were flash mixed for $3 \mathrm{~min}$ at $230 \mathrm{r} \cdot \mathrm{min}^{-1}$, the flocculants were dosed followed by another $10 \mathrm{~s}$ of flash mixing. The jar stirrer speed was then reduced to $80 \mathrm{r} \cdot \mathrm{min}^{-1}$ and mixing continued for another $7 \mathrm{~min}$. The jar stirrer was switched off and the sludge was allowed to settle for $10 \mathrm{~min}$. The suspended solids of the respective supernatants were then determined gravimetrically. Performance of the flocculants was based on the lowest amount of suspended solids in the respective supernatants. For the purpose of this study, the flocculants evaluated, i.e., XP13-025, XP13-026, XP13-027, XP13-5511 and XP13-5182P were labelled as $\mathrm{C} 1, \mathrm{C} 2, \mathrm{C} 3$ and $\mathrm{C} 4$, respectively.

\section{Analytical methods}

The suspended solids (SS) were analysed gravimetrically by filtering $100 \mathrm{~mL}$ aliquots through Whatman GF/C filter paper under vacuum, capillary suction tests (CST) were performed using a Triton 304 CST unit (Triton Electronics Ltd, England), and pH was measured using the Hach model HQ40d multi-meter and a calibrated Hach PHC101 gel-filled $\mathrm{pH}$ probe. The metal ions were determined by inductively-coupled plasma/optical emission spectrometry (ICP-OES) using an Agilent (Agilent Technologies, USA). COD, ammonia-nitrogen and nitrate-nitrogen were determined using a calibrated Hach DR 890 colorimeter and validated Hach methods 8000, 8155 and 8192, respectively. Phenols and biological oxygen demand $\left(\mathrm{BOD}_{5}\right)$ were analysed using Standard Methods (APHA, 2012). 
The dichloromethane liquid-liquid extractives of the feed and effluent were characterised using an Agilent 7890A gas chromatograph (Agilent Technologies, USA) equipped with an Agilent 5975C inert mass selective detector (MSD) (Agilent Technologies, USA). A DB-5MS capillary column was used (30 m x $0.3 \mathrm{~mm}$ ID x $0.25 \mu \mathrm{m})$ with split injection mode (10:1). Helium $\left(1.1 \mathrm{~mL} \cdot \mathrm{min}^{-1}\right)$ was used as the carrier gas and the GC oven was programmed at a temperature gradient of $40^{\circ} \mathrm{C}$ to $300^{\circ} \mathrm{C}$ over a period of $35 \mathrm{~min}$. The electron ionisation (EI) spectra of the compounds were identified by searching the National Institute of Standards and Technology (NIST05) mass spectral library.

\section{Laboratory scale nickel-catalyst reactor parameters}

The nickel catalyst was activated using sodium hypochlorite for a period of $24 \mathrm{~h}$ before treating the CGWW. The $\mathrm{pH}$ of the CGWW was maintained at 9.5 to prevent leaching of the metal from the catalyst and the temperature was maintained at $50^{\circ} \mathrm{C}$ to increase the oxidation reaction rate. The operational parameters for the reactor are indicated in Table 1. The CGWW was sampled before and after treatment and analysed for phenol, COD, $\mathrm{BOD}_{5}$ and ammonia-nitrogen.

All equipment and instrumentation used during the pilot plant study were calibrated according to the manufacturer's instructions and the test methods were validated according to the ISO/IEC 17025:2005 technical requirements.

\section{RESULTS and DISCUSSION}

\section{Identification and quantification of the exogenous inoculum}

The respective hydrated inocula were plated out to identify and quantify the culturable micro-organisms used for enhancing the performance of the H-FFBR treating the CGWW. The heterotrophic plate count (HPC) ranged between $1.3 \times 10^{6}$ and $3.0 \times 10^{9} \mathrm{cfu} \cdot \mathrm{g}^{-1}$, Pseudomonas spp. ranged between $8.0 \times 10^{4}$ and $4.0 \times 10^{9} \mathrm{cfu} \cdot \mathrm{g}^{-1}$ and Bacillus spp. ranged between $4.0 \times 10^{6}$ and $1.9 \times 10^{9} \mathrm{cfu} \cdot \mathrm{g}^{-1}$. The diatoma cell count was $5.4 \times 10^{4} \mathrm{cells} \cdot \mathrm{g}^{-1}$ (Table 2).

The bacterial species in inoculum PA1 were identified as Bacillus pumilus, Bacillus amyloliquifaciens, Bacillus subtilis, Rhodococcus spp, Pseudomonas spp and Pseudomonas putida. The bacterial species in inoculum PA2 were identified as Bacillus amyloliquifaciens, Bacillus subtilis and Pseudomonas putida. The main bacterial species in inoculum PA3 were identified as Pseudomonas putida. There were other pseudomonads present which were not identified. The diatoma in inoculum PA4 were identified as Cocconeis spp and Nitzschia spp. PA4 was included in the study since diatoma can facilitate spontaneous flocculation of bacteria to improve the quality of the effluent and prevent cells from being washed out of the bioreactor (Farooqi et al., 2008).

The indigenous population in the H-FFBR consisted mainly of Pseudomonas stutzeri, Aeromonas hydrophila and Bacillus cereus.

\section{Microbial degradation of organic compounds}

Most phenol-degrading bacteria can degrade other aromatic compounds; however, there are differences between the strains

\begin{tabular}{|c|c|}
\hline $\begin{array}{c}\text { TABLE } 1 \\
\text { Laboratory scale fixed-bed metal oxide catalyst reactor } \\
\text { operating parameters }\end{array}$ \\
\hline Parameter & Setting \\
\hline Effluent flow rate & $40 \mathrm{~mL} \cdot \mathrm{h}^{-1}$ \\
\hline Oxidant flow rate & $10 \mathrm{~mL} \cdot \mathrm{h}^{-1}$ \\
\hline Temperature & $50^{\circ} \mathrm{C}$ \\
\hline $\begin{array}{c}\text { Liquid hourly space velocity } \\
\text { (LHSV) }\end{array}$ & $1.0 \mathrm{~h}^{-1}$ \\
\hline Catalyst volume & $50 \mathrm{~mL}$ \\
\hline $\mathrm{pH}$ & 9.5 \\
\hline
\end{tabular}

TABLE 2

Microbial population of the respective exogenous microorganisms

\begin{tabular}{|c|c|c|c|c|}
\hline $\begin{array}{c}\text { Exogenous } \\
\text { inoculum }\end{array}$ & $\begin{array}{c}\text { HPC } \\
\mathbf{c f u} \cdot \mathbf{g}^{-\mathbf{1}}\end{array}$ & $\begin{array}{c}\text { Pseudomonas } \\
\mathbf{s p p .} \\
\mathbf{c f u} \cdot \mathbf{g}^{-1}\end{array}$ & $\begin{array}{c}\text { Bacillus } \\
\mathbf{s p p .} \\
\mathbf{c f u} \cdot \mathbf{g}^{-1}\end{array}$ & $\begin{array}{c}\text { Diatoma } \\
\mathbf{c e l l s} \cdot \mathbf{g}^{-1}\end{array}$ \\
\hline $\mathrm{PA} 1$ & $2.2 \times 10^{9}$ & $1.0 \times 10^{9}$ & $1.9 \times 10^{9}$ & $\mathrm{na}$ \\
\hline $\mathrm{PA} 2$ & $3.0 \times 10^{9}$ & $4.0 \times 10^{9}$ & $1.6 \times 10^{9}$ & $\mathrm{na}$ \\
\hline $\mathrm{PA} 3$ & $2.4 \times 10^{9}$ & $1.6 \times 10^{9}$ & $1.0 \times 10^{9}$ & $\mathrm{na}$ \\
\hline $\mathrm{PA} 4$ & $1.3 \times 10^{6}$ & $8.0 \times 10^{4}$ & $4.0 \times 10^{6}$ & $5.4 \times 10^{3 *}$ \\
\hline
\end{tabular}

na: not applicable

${ }^{*} 3.2 \times 10^{3}$ Cocconeis spp and $2.2 \times 10^{3}$ Nitzschia spp.

Samples were analysed in triplicate and the average values presented

with respect to the kind of aromatic compounds biodegraded (Ambujom, 2001). The critical step in biodegradation is the cleavage of the aromatic ring. The initial catabolic step involves the insertion of two hydroxyl groups on the aromatic nucleus. Ring fission proceeds via the meta or the ortho pathway of the hydroxylated aromatic compound (Mulcahy, 1993). The meta pathway is plasmid encoded and the ortho pathway is chromosomally encoded (Ambujom, 2001). The bacterial consortium that degrades via the ortho pathways has a slower rate of degradation compared to the meta-cleaving bacterial consortium (Ambujom, 2001).

Rhodococcus, Pseudomonas and Burkholderia degrade $\mathrm{C}_{5}-\mathrm{C}_{16}$ alkanes, fatty acids, alkyl benzenes and cycloalkanes (Das and Chandran, 2011). Rhodococcus and Pseudomonas can utilise phenols, aliphatic and aromatic hydrocarbons as carbon sources and are the most active bacteria in coal gasification wastewater (Meng et al., 2015). Pseudomonas and Burkholderia produce the required enzymes to access hydantoins and hydantoin-like molecules as metabolic substrates (Dürr et al., 2006). Pseudomonas has also been reported to biodegrade aromatics such as pyrocatechol, alpha-naphthol, hydroquinone, naphthalene, isoquinoline, indole and sulfonated aromatic compounds (Nawawi et al., 2014). Pseudomonas aeruginosa and Pseudomonas stutzeri degrade phenol (Arunkumar and Anitha, 2014) and several Pseudomonas species have been isolated and identified as cyanide-degrading bacteria which utilise cyanide as a source of carbon and nitrogen. Cyanide metabolising bacteria include Bacillus species such as Bacillus megaterium, Bacillus pumilus, Bacillus stearothermophilus and Bacillus cereus. (Perumal et al., 2013). Pseudomonas and Bacillus spp. are capable of heterotrophic nitrification (Lin et al., 2006). Pseudomonas and Aeromonas produce enzymes such as protease and lipases which assist with the reduction of waste activated sludge (Yasin et al., 2014) and have been reported to be tolerant towards heavy metals found in CGWW (Kasan and Baecker,1989). 


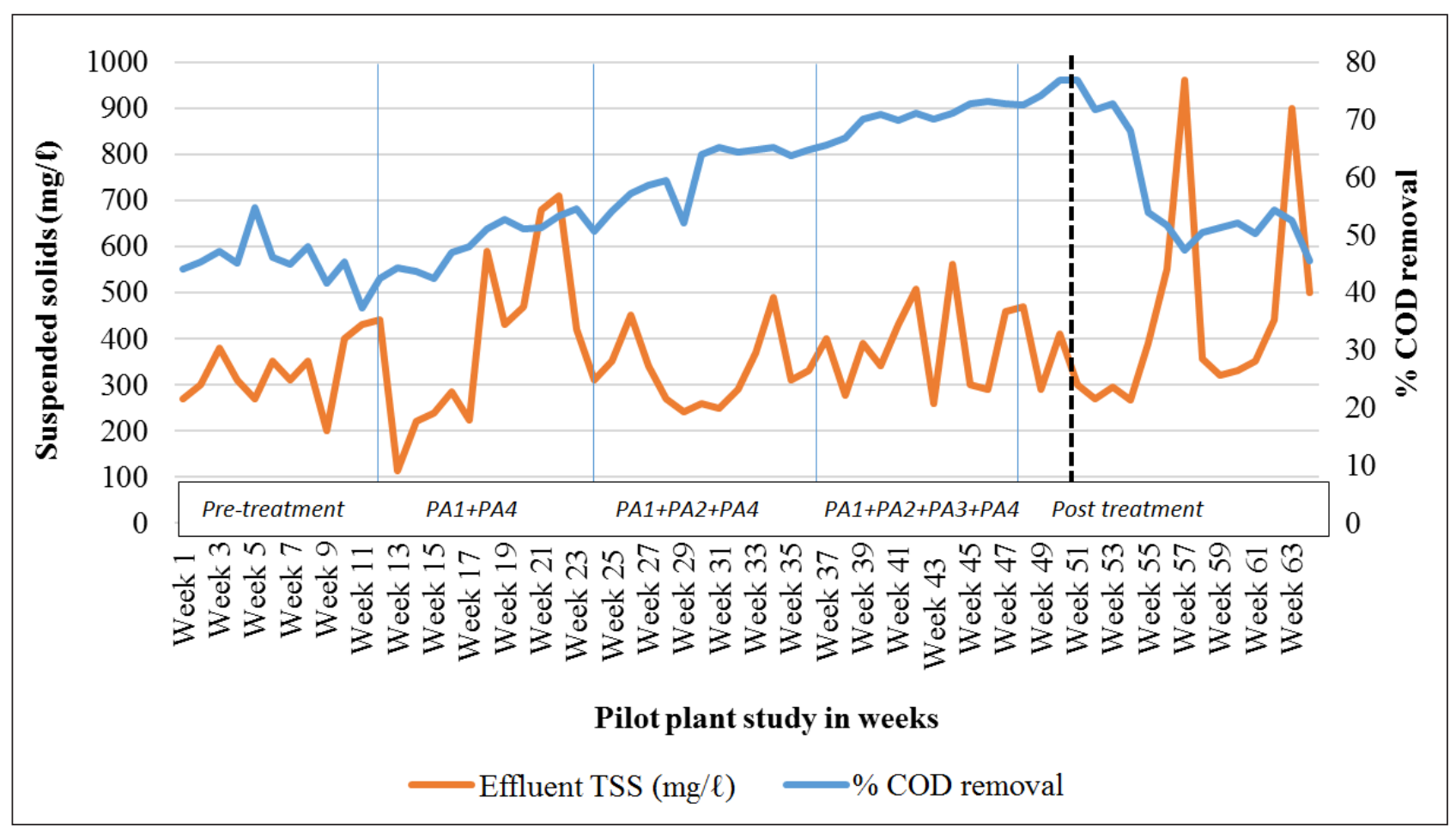

Figure 2

Effect of the exogenous inoculum on \% COD removal and the suspended solids of the treated effluent during the pilot plant study

\section{Reactor performance in removing soluble COD and suspended solids}

The co-inoculation sequence was based on the potential removal of COD as follows:

- Week 1 to 12: PA1 (50 mg. $\left.\mathrm{L}^{-1}\right)$ and PA4 (20 mg. $\left.\mathrm{L}^{-1}\right)$

- Week 12 to 24: PA1 (50 mg. $\left.\mathrm{L}^{-1}\right), \mathrm{PA} 2\left(150 \mathrm{mg} \cdot \mathrm{L}^{-1}\right)$ and PA4 $\left(20 \mathrm{mg} \cdot \mathrm{L}^{-1}\right)$

- Week 24 to 36: PA1 (50 mg. $\left.\mathrm{L}^{-1}\right), \mathrm{PA} 2\left(150 \mathrm{mg} \cdot \mathrm{L}^{-1}\right)$ PA3 (150 mg. $\left.\mathrm{L}^{-1}\right)$ and PA4 (20 mg. $\left.\mathrm{L}^{-1}\right)$

The weekly average COD and SS data for the pre-treatment, exogenous inoculations and post-treatment phase is presented in Fig. 2 and Table 3, respectively. The cost per treatment programme was calculated on an average purchasing price of $33 € \cdot \mathrm{kg}^{-1}$ dry inoculum.

The average soluble COD of the feed was relatively constant throughout the pilot plant study (Table 2). The inoculation with PA1 and PA 4 increased the removal of soluble COD by $4 \%(45 \%$ to $49 \%$ ) which was not significant ( $p>0.05$ ) when compared to the baseline data. The addition of PA2 to the inoculum increased the removal of soluble COD by $12 \%$ ( $49 \%$ to $61 \%$ ) which was significant $(p<0.05)$ when compared to the baseline data and the inoculation without PA2. The addition of PA3 to the inoculum increased the removal of soluble COD by a further $9 \%(61 \%$ to $70 \%)$ which was significant $(p<0.05)$ when compared to the baseline data and inoculation without PA3. A 25\% improvement in the removal of soluble COD was achieved at a cost of 12.21 $€ \cdot \mathrm{m}^{-3}$. The removal of soluble COD started to decrease about 2 weeks after the last inoculation (Fig. 2), suggesting that the gene transfer of catabolic plasmids between the bacterial populations was dependant on the survival of donor plasmids which had a limited long-term impact. The cost of the bio-augmentation programme could potentially be reduced from $12.21 € \cdot \mathrm{m}^{-3}$ to $1.74 € \cdot \mathrm{m}^{-3}$ by inoculating the bioreactor weekly rather than daily.

The increase in COD removal indicated that more compounds were available for degradation. Even though a $70 \%$ removal in COD was achieved, the effluent did not meet the Minimal National Standards (MINAS) for discharge (125 mg. $\mathrm{L}^{-1}$ ), nor the global effluent standards for refineries, i.e., World Bank (150 mg. $\left.\mathrm{L}^{-1}\right)$, USA (30 $\left.\mathrm{mg} \cdot \mathrm{L}^{-1}\right)$, European Union (30 mg. $\mathrm{L}^{-1}$ to $225 \mathrm{mg} \cdot \mathrm{L}^{-1}$ ) and Nigeria $\left(40 \mathrm{mg} \cdot \mathrm{L}^{-1}\right)$ (Mazema et al., 2008).

Inoculation of the bioreactor increased the dispersed biomass which settled very slowly and consequently was washed out from the system resulting in increased SS in the clarifier overflow (Table 3). Therefore, daily inoculation was required to replenish the washed-out biomass. The inoculation with the diatoma containing inoculum, PA4, did not improve the settling rate of the biomass as anticipated. Thus, the SS of the effluent did not meet the MINAS limit (20 mg. $\mathrm{L}^{-1}$ ), nor the global effluent standards for refineries, i.e., World Bank (30 mg. $\left.\mathrm{L}^{-1}\right)$, USA (30 mg. $\left.\mathrm{L}^{-1}\right)$, European Union (2 mg. $\mathrm{L}^{-1}$ to $80 \mathrm{mg} \cdot \mathrm{L}^{-1}$ ) (Mazema et al., 2008).

\section{Effect of flocculants on sludge settling and dewatering properties}

Cationic flocculants (Table 4) with different cationicities and molecular weights were tested between $1 \mathrm{~kg} \cdot \mathrm{t}^{-1}$ and $3 \mathrm{~kg} \cdot \mathrm{t}^{-1} \mathrm{dry}$ solids to improve the biomass (activated sludge) settling rate and dewatering properties. Cationic flocculants were selected since sludge flocs have a negative charge due to the ionisation of the anionic functional groups and are not likely to aggregate naturally due to repulsive electrostatic forces and hydration interactions between them (Liu and Tay, 2004).

Flocculant $\mathrm{C} 1$, dosed at $2 \mathrm{~kg} \cdot \mathrm{t}^{-1}$ dry sludge solids, reduced the suspended solids by $70 \%$ ( 180 to $54 \mathrm{mg} \cdot \mathrm{L}^{-1}$ ) which will reduce the total COD of the effluent due to less carry-over of colloidal and suspended solids. The dewatering properties of 
TABLE 3

Average soluble COD removal and SS per treatment phase versus cost. Number of samples analysed per treatment phase: 60

\begin{tabular}{|l|c|c|c|c|c|}
\hline \multicolumn{1}{|c|}{ Parameter } & Pre-treatment & PA1+PA4 & PA1+PA2+PA4 & $\begin{array}{c}\text { PA1+PA2+ } \\
\text { PA3+PA4 }\end{array}$ & Post treatment \\
\hline Feed COD $\left(\mathrm{mg} \cdot \mathrm{L}^{-1}\right)$ & $1710 \pm 60$ & $1750 \pm 20$ & $1690 \pm 40$ & $1720 \pm 70$ & $1750 \pm 50$ \\
\hline Effluent COD $\left(\mathrm{mg} \cdot \mathrm{L}^{-1}\right)$ & $940 \pm 70$ & $810 \pm 80$ & $570 \pm 40$ & $480 \pm 40$ & $870 \pm 70$ \\
\hline$\%$ COD removal & $45 \pm 4.1$ & $49 \pm 4.0$ & $61 \pm 4.7$ & $70 \pm 2.3$ & $62 \pm 12$ \\
\hline Effluent SS $\left(\mathrm{mg} \cdot \mathrm{L}^{-1}\right)$ & $304 \pm 87$ & $422 \pm 158$ & $345 \pm 74$ & $368 \pm 107$ & $480 \pm 289$ \\
\hline Treatment cost ${ }^{1}\left(€ \cdot \mathrm{m}^{-3}\right)$ & & 1.65 & 7.26 & 12.21 & \\
\hline
\end{tabular}

${ }^{1}$ Average value per treatment phase \pm standard deviation

the sludge were measured using a capillary suction tester (CST). The specific CST (SCST) [(CST (s)/solids $\left.\left(\mathrm{g} \cdot \mathrm{L}^{-1}\right)\right]$ increased from $61 \mathrm{~s} \cdot \mathrm{L} \cdot \mathrm{g}^{-1}$ to $154 \mathrm{~s} \cdot \mathrm{L} \cdot \mathrm{g}^{-1}$ thus indicating a significant improvement $(p<0.05)$ in the sludge dewatering rate due to improved floc structure. The unit treatment cost was calculated to be $2.5 € \cdot \mathrm{t}^{-1}$ of dry sludge solids.

\section{Removal of nitrogenous compounds}

No nitrification took place in the H-FFBR since there was no difference between the average influent nitrate-nitrogen $\left(\mathrm{NO}_{3}-\mathrm{N}\right)$ $\left(5.7 \mathrm{mg} \cdot \mathrm{L}^{-1}\right)$ and the average effluent $\mathrm{NO}_{3}-\mathrm{N}\left(5.7 \mathrm{mg} \cdot \mathrm{L}^{-1}\right)$. No increase in nitrate also indicated that hydantoins were not removed (Turner and Wernberg, 1985). The $14.5 \%$ difference between the average influent ammonium-nitrogen $\left(\mathrm{NH}_{4}-\mathrm{N}\right)$ $\left(415 \mathrm{mg} \cdot \mathrm{L}^{-1}\right)$ and the average effluent $\mathrm{NH}_{4}-\mathrm{N}\left(355 \mathrm{mg} \cdot \mathrm{L}^{-1}\right)$ was most probably due to evaporative stripping rather than nitrification having taken place. The average concentration of cations was $89 \mathrm{mg} \cdot \mathrm{L}^{-1}$ for sodium $\left(\mathrm{Na}^{+}\right) ; 4.5 \mathrm{mg} \cdot \mathrm{L}^{-1}$ for calcium $\left(\mathrm{Ca}^{2+}\right)$ and $2.2 \mathrm{mg} \cdot \mathrm{L}^{-1}$ for magnesium $\left(\mathrm{Mg}^{2+}\right)$. The molar ratio of monovalent- to-divalent cations was higher than $2(\mathrm{M} / \mathrm{D}>2)$ thus inhibiting nitrification and the removal of cyanides, thiocyanates, aromatic amines and ammonia which form part of the soluble COD (Sharma and Philip, 2014). The carbon:nitrogen ratio $(\mathrm{C} / \mathrm{N})$ was greater than 1.5 thus heterotrophs dominated the microbial population inhibiting the growth of autotrophic nitrifiers. Compounds having a similar structure to ammonia can interfere with the active site of ammonia mono-oxygenase and metal-binding compounds can reduce the availability of copper thus inactivating the enzymes involved in the nitrification process (Michaud et al., 2006).

\section{Removal of organic compounds}

Gas chromatography-mass spectroscopy (GC/MS) of the feed and effluent indicated the presence of 2-methylcyclopentanone, 3-methylcyclopentanone, aniline, o-phenol, 5-quinolinol, 1-methyl-2-acetylindole, $\mathrm{I}(2 \mathrm{H})$-isoquinolinone, butenoic acid, hexanoic acid, heptanoic acid, octanoic acid, n-hexadecanoic acid, 2-methylbenzoic acid, 3-methylbenzoic acid, 4-methylbenzoic acid, 2,5-dimethylbenzoic acid, 4-ethylbenzoic acid 3,4-dimethylbenzoic acid, 3,5-dimethylbenzoic acid, 4-(1-methylethyl)benzoic acid, 5,5-dimethylhydantoin (DMH), 5-ethyl5-methylhydantoin (EMH) and squalene.

The indigenous and exogenous microbial species were effective in biodegrading/oxidising the compounds such as saturated carboxylic acids $\left(\mathrm{C}_{4}\right.$ to $\mathrm{C}_{16}$ ), aniline (cyclic amine), 5-quinolinol (benzopyridine), 1-methyl-2-acetylindole (heterocyclic ketone), o-phenols. However, they were not effective in biodegrading the benzoic acids (aromatic carboxylic acids), trans-2-butenoic acid (short-chain unsaturated carboxylic acid), $\mathrm{I}(2 \mathrm{H})$-isoquinolinone (heterocyclic amine), hydantoins (highly polar heterocyclic compounds), long-chain hydrocarbon (carbon length $>\mathrm{C}_{15}$ ) and

\begin{tabular}{|c|c|c|}
\hline \multicolumn{3}{|c|}{$\begin{array}{c}\text { TABLE } 4 \\
\begin{array}{c}\text { Cationic flocculants evaluated for biomass settling and } \\
\text { sludge dewatering }\end{array}\end{array}$} \\
\hline Flocculant & Cationicity (mole \%) & $\begin{array}{c}\text { Molecular weight (x } 10^{6} \\
\text { Dalton) }\end{array}$ \\
\hline $\mathrm{C} 1$ & 1 to 5 & 10 to 15 \\
\hline $\mathrm{C} 2$ & 5 to 10 & 5.0 to 6.5 \\
\hline $\mathrm{C} 3$ & 10 to 15 & 5.0 to 6.5 \\
\hline $\mathrm{C} 4$ & 10 to 15 & 8.0 to 10 \\
\hline $\mathrm{C} 5$ & 15 to 20 & 8.0 to 10 \\
\hline
\end{tabular}

squalene. These compounds can be classified as poorly or nonbiodegradable and are thus contributing to the remaining 30\% COD. Unidentified organic compounds, inorganic compounds and nitrogenous compounds such as ammonia, thiocyanate, and cyanide will also contribute to the soluble COD.

Qualitative analyses of the feed indicated that total phenols ranged between $100 \mathrm{mg} \cdot \mathrm{L}^{-1}$ and $150 \mathrm{mg} \cdot \mathrm{L}^{-1}$, carboxylic acids between $150 \mathrm{mg} \cdot \mathrm{L}^{-1}$ and $250 \mathrm{mg} \cdot \mathrm{L}^{-1}$, hydantoins between $200 \mathrm{mg} \cdot \mathrm{L}^{-1}$ and $250 \mathrm{mg} \cdot \mathrm{L}^{-1}$, oil and grease (dichloromethane extraction) between $10 \mathrm{mg} \cdot \mathrm{L}^{-1}$ and $30 \mathrm{mg} \cdot \mathrm{L}^{-1}$, nitrogen- and sulphur-containing organics between $20 \mathrm{mg} \cdot \mathrm{L}^{-1}$ and $30 \mathrm{mg} \cdot \mathrm{L}^{-1}$. Qualitative analyses of the effluent indicated that total phenols ranged between $0.35 \mathrm{mg} \cdot \mathrm{L}^{-1}$ and $5.0 \mathrm{mg} \cdot \mathrm{L}^{-1}$, carboxylic acids $<20 \mathrm{mg} \cdot \mathrm{L}^{-1}$, and nitrogen- and sulphur-containing compounds between $20 \mathrm{mg} \cdot \mathrm{L}^{-1}$ and $30 \mathrm{mg} \cdot \mathrm{L}^{-1}$.

\section{Combination of technologies to meet discharge requirements}

Preliminary laboratory results using a laboratory-scale fixedbed metal-oxide catalyst reactor (Table 1 ) showed a significant removal $(p<0.05)$ of phenols $\left(150 \mathrm{mg} \cdot \mathrm{L}^{-1}\right.$ to $\left.<10 \mathrm{mg} \cdot \mathrm{L}^{-1}\right)$, COD $\left(1710 \mathrm{mg} \cdot \mathrm{L}^{-1}\right.$ to $\left.<10 \mathrm{mg} \cdot \mathrm{L}^{-1}\right), \mathrm{BOD}_{5}\left(78 \mathrm{mg} \cdot \mathrm{L}^{-1}\right.$ to $\left.<10 \mathrm{mg} \cdot \mathrm{L}^{-1}\right)$ and ammonium-nitrogen $\left(450 \mathrm{mg} \cdot \mathrm{L}^{-1}\right.$ to $\left.<10 \mathrm{mg} \cdot \mathrm{L}^{-1}\right)$. The unit treatment cost (excluding operational costs) for the high-quality effluent was calculated to be approximately $25 € \cdot \mathrm{m}^{-3}$ of effluent The choice of technology, or combination of technologies, will largely depend on the cost to achieve the quality of effluent required to meet discharge requirements and the respective penalties imposed for not meeting the discharge requirements.

\section{CONCLUSIONS}

The study showed that the exogenous bacteria enhanced the removal of COD; however, the performance of the H-FFBR was dependent on the survival of the donor plasmids (exogenous inoculum) which had a limited long-term impact. Bioaugmentation did not improve the quality of the CGWW sufficiently to meet the discharge requirements in terms of COD, ammonia-nitrogen and suspended solids. Bio-augmentation 
can be used as a pre-treatment step; however, the treatment cost would not be financially sustainable due to the large volumes of CGWW generated by refineries. Alternative more cost-effective chemical and physical technologies should be investigated for treating the CGWW.

\section{ACKNOWLEDGEMENTS}

The authors would like to thank Buckman Africa for financing the chemical and microbiological analyses and Sasol Group Technology (Pty) Ltd for the use and operation of the pilot plant.

\section{REFERENCES}

APHA (2012) Standard Methods for the Examination of Water and Wastewater (22 $2^{\text {nd }}$ edn). American Public Health Association/ American Water Works Association/Water Environment Federation, Washington DC. ISBN-13: 978-087553-0130.

AMBUJOM S (2001) Studies on composition and stability of a large membered bacterial consortium degrading phenol. Microbiol. Res. 156 293-301. http://dx.doi.org/10.1078/0944-5013-00091

ARUNKUMAR D and ANITHA A (2014) Biodegradation of phenol and emulsification properties of native microorganisms from coal carbonization plant. Int. J. Appl. Biol. Pharm. Technol. 5 (4) 249-256.

AYUN A, NAS B and BERKTAY A (2008) Influence of organic loading rates on COD removal and sludge production in moving bed biofilm reactor. Environ. Eng. Sci. 25 (9) 1311-1316. http://dx.doi.org/10.1089/ ees.2007.0071

BAI Y, SUN Q, ZHOU C and WEN D (2010) Bioaugmentation treatment for coking wastewater containing pyridine and quinolone in a sequencing batch reactor. Appl. Microbiol. Biotechnol. 87 1943-1951. http://dx.doi.org/10.4061/2011/941810

DAS N and CHANDRAN P (2011) Microbial degradation of petroleum hydrocarbon contaminants: An overview. Biotechnol. Res. Int. (doi: $10.4061 / 2011 / 941810)$

DÜRR R, VIELHAUER O, BURTON SG, COWAN DA and PUANL A (2006) Distribution of hydantoinase activity in bacterial isolates from geographically distinct environmental sources. J. Mol. Catal. B:Enzymatic 39 160-165 (doi:10.1016/j.molcatb.2006.01.017). http:// dx.doi.org/10.1016/j.molcatb.2006.01.017

DOMDE P, KAPLEY A and PUROHIT HJ (2007) Impact of bioaugmentation with a consortium of bacteria on the remediation of wastewater-containing hydrocarbons. Environ. Sci. Pollut. Res. 14 (1) 7-11. http://dx.doi.org/10.1065/espr2006.11.358

FAROOQI LH, BASHEER F and AHMAD T (2008) Studies on biodegradation of phenols and $\mathrm{m}$-cresols by upflow anaerobic sludge blanket and aerobic sequential batch reactor. Global Network Environ. Sci. Technol. J. 10 (1) 39-46.

ISHAK S, MALAJAHMAD A and ISA MH (2012) refinery wastewater biological treatment: A short review. J. Sci. Ind. Res. 71 251-256.

KASAN HC and BAECKER AW (1989) Activated sludge treatment of coal-gasification effluent in a petrochemical plant - Metal accumulation by heterotrophic bacteria. Water Sci. Technol. 21 (4-5) 297-303.

LI F, LIU Q, YAN S, ZHAO J, FAN B, FENG H and CAO W (2014) A review of hybrid process to treat coal gasification wastewater. $A d v$. Mater. Res. 955-959 2196-2199. http://dx.doi.org/10.4028/www. scientific.net/AMR.955-959.2196

LI H, HAN H, DU H and WANG W (2011) Inhibition and recovery of nitrification in treating real coal gasification wastewater with moving bed biofilm reactor. J. Environ. Sci. 23 (4) 568-574. http://dx.doi. org/10.1016/S1001-0742(10)60449-4

LIN Y, TANAKA S and KONG H (2006) Characterisation of a new isolated heterotrophic nitrifying bacterium. Water Pract. Technol. J. 1 (3) http://dx.doi.org/10.2166/wpt.2006052

LUI Y and TAY JH (2004) State of the art of biogranulation technology for wastewater treatment. Biotechnol. Adv. 22 533-563. http://dx.doi. org/10.1016/j.biotechadv.2004.05.001

MAZEMA HK, ALLY SH, KAMISH W and PETERSEN AM (2008) A pilot study into available upstream cleaner production technologies for the petroleum refining industry to meet the requirements of the waste discharge system. WRC Report No. 1673/1/08. Water Research Committee, South Africa.
MENG X, LI H, SHENG Y, CAO H and ZHANG Y (2015) Analysis of a diverse bacterial community and degradation of organic compounds in a process for coking wastewater treatment. Desalin. Water Treat. doi: 10.1080/19443994.2015.1100556. http://dx.doi.org/10.1080/1944 3994.2015.1100556

MICHAUD L, BLANCHETON JP, BRUNI V and PIEDDRAHITA (2006) Effect of organic carbon on heterotrophic populations and nitrification by biological filters. Aquacult. Eng. 34 (3) 224-233. http:// dx.doi.org/10.1016/j.aquaeng.2005.07.005

MULCAHY G (1993) The characterization of Pseudomonas species from a commercial bioaugmentation product. $\mathrm{PhD}$ thesis, School of Biological Sciences, Dublin City University.

NAWAWI NM, AHMAD SA, SHUKOR MY, SYED MA and IBRAHIM AL (2014) Isolation and characterization of phenol-degrading microorganism: J. Environ. Biorem. Toxicol. 2 (1) 11-22.

OECD (2010) Guidance document on horizontal gene transfer between bacteria. In: Safety Assessment of Transgenic Organisms, Volume 4: OECD Consensus Documents. OECD Publishing, Paris. URL: http:// dx.doi.org/10.1787/9789264096158-11-en (Accessed 12 March 2016). http://dx.doi.org/10.1787/9789264096158-11-en

PEI R and GUNSCH CK (2009) Plasmid conjugation in an activated sludge microbial community. Environ. Eng. Sci. 26 (4) 825-826. http:// dx.doi.org/10.1089/ees.2008.0236

PERUMAL M, PRABAKARAN J and KAMARAJ M (2013) Isolation and characterisation of potential cyanide degrading Bacillus nealsonii from different industrial effluents. Int. J. ChemTech. Res. 5(5) 2357-2364.

RATCLIFFE M, ROGERS C, MERDINGER M, PRINCE J, MABUZA $\mathrm{T}$ and JOHNSON CH (2006) Treatment of high strength chemical industry wastewater using moving bed biofilm reactor (MBBR) and powdered activated carbon (PAC) technology. WEFTEC 18 16771694. http://dx.doi.org/10.2175/193864706783750303

RUBALCABA A, SUAREZ-OJEDA ME, STÜBER F, FORTUNY A, BENGOA C, METCALFE I, FONT J, CARRERA J and FABREGAT A (2007) Phenol wastewater remediation: advanced oxidation processes coupled to a biological treatment. Water Sci. Technol. 55 (12) 221-227. http://dx.doi.org/10.2166/wst.2007.412

SHARMA NK and PHILIP L (2014) Treatment of phenolics, aromatic hydrocarbons, and cyanide-bearing wastewater in individual and combined anaerobic, aerobic, and anoxic bioreactors. Appl. Biochem. Biotechnol. 175 (1) 300-322.

STAMOUDIS VC and LUTHY RG (1980) Biological removal of organic constituents in quench water from a slagging, fixed-bed coal gasification pilot plant. United States Department of Energy (contract W32109-Eng-38). URL: http://www.osti.gov/scitech/servlets/purl/5531569 (Accessed 2 January 2014).

TAVARES DOS PASSOS C, MICHELON M, FERNANDES DE MEDEROS BURKERT J, KALIL SJ and VEIGA BURKET CA (2010) Biodegradation of phenol by free and encapsulated cells of a new Aspergillus sp. isolated from a contaminated site in southern Brazil. Afr. J. Biotechnol. 9 (40) 6716-6720.

TURNER CD and WERNBERG K (1985) Biological treatment of high strength ammonia wastewater using a four stage RBC. In: Proceedings of the North Dakota Academy of Science - 77th Annual Meeting, 26-28 April 1985, Dakota, USA.

WANG X, HU M, XIA Y, WEN X and DING K (2012) Pyrosequencing analysis of bacterial diversity of 14 wastewater treatment systems in China. Appl. Environ. Microbiol. 78 (19) 7042-7047. http://dx.doi. org/10.1128/AEM.01617-12

WASILKOWSKI D, SWEDZIOL Z and MROZIK A (2012) The applicability of genetically modified microorganisms in bioremediation of contaminated environments. CHEMIK 66 (8) 817-826

YASIN NHM, SANCHEZ-TORRES V and MAEDA T (2014) Enhances reduction of waste activated sludge at low temperature by locally isolated Pseudomonas sp. VNT and Aeromonas sp. VNT. Bioresour. Technol. 174 134-141. http://dx.doi.org/10.1016/j. biortech.2014.10.005

ZHOU X, LI Y and ZHAO Y (2014) Removal of characteristics of organics and nitrogen in novel four-stage biofilm integrated system for enhanced treatment of coking wastewater under different HRTs. RSC Adv. 4 51620-15629. http://dx.doi.org/10.1039/c4ra00128a 